\title{
Motor Vehicle Operators
}

National Cancer Institute

\section{Source}

National Cancer Institute. Motor Vehicle Operators. NCI Thesaurus. Code C122486.

The group of professions that include ambulance drivers and attendants, bus drivers, driver/sales workers, heavy and tractor-trailer truck drivers, light truck or delivery service drivers, and taxi drivers and chauffeurs. 